\title{
Charting the State of Social Cohesion in Hong Kong*
}

\author{
Joseph Chan and Elaine Chan
}

\begin{abstract}
This paper reports findings from the first social cohesion survey in Hong Kong. Social cohesion is understood as a multi-dimensional concept, having a horizontal dimension which is concerned with both feelings and actions of members of society, and a vertical dimension that taps those between society and the government. It is found that horizontally, society feels cohesive but the feeling is not supported by corresponding behaviour such as participation in organizations and engagement in giving and helping. Vertically, society has much higher trust in bureaucracies of justice administration than the executive branch of the government. The level of civic engagement is respectable despite a general dissatisfaction with government performance. We conclude that however cohesively society feels, it is achieved with little institutional mediation and social engagement. We postulate that this is possible because lending support to advocacy groups, participation in small group activities and close family ties might have rendered institutional mediation less significant.
\end{abstract}

The concept of social cohesion has been popular among policy makers $^{1}$ and international regimes ${ }^{2}$ in Western democratic societies since the 1990s. Given the growing cultural and ethnic diversity in society, the challenge of globalization, widening disparity between the rich and the poor, new forms of exclusion, political threats and social

* An earlier version of this article was presented at the Conference on Social Cohesion, organized by the Faculty of Social Sciences, the University of Hong Kong and The Hong Kong Council of Social Service, 28-29 November 2003. The authors would like to thank the Faculty of Social Sciences, the University of Hong Kong for funding the questionnaire survey upon which this article is based.

1. The Canadian government was one of the first countries to pioneer the concept of social cohesion and the idea was included as part of its official agenda to promote multiculturalism in the 1990s. M. Sharon Jeannotte, "Social cohesion: insights from Canadian research," paper presented at the Conference on Social Cohesion, organized by the Faculty of Social Sciences, the University of Hong Kong, and the Hong Kong Council of Social Service, 28-29 November 2003.

2. The European Union has allocated huge sums of money to the Structural and Cohesion Funds and the EMPLOYMENT initiative to tackle societal issues that can undermine social cohesion. See M. Sharon Jeannotte, "Social cohesion from around the world: an international comparison of definitions and issues," Paper SRA-309 (Ottawa: Strategic Research and Analysis Directorate, Department of Heritage, 2000). The Council of Europe takes a more positive approach and towards the end of 1990s it established the European Committee for Social Cohesion. See Gabriella BattainiDragoni and Stefano Dominioni, "The Council of Europe's strategy for social cohesion," paper presented at the Conference on Social Cohesion. The World Bank and the Organization for Economic Co-operation and Development (OECD) are also concerned with social cohesion. See Jo Ritzen, William Easterly and Michael Woolcock, "On good politicians and bad policies: social cohesion, institutions, and growth," World Bank Policy Research Working Paper 2448 (Washington, DC: World Bank, 2000).

(c) The China Quarterly, 2006 doi: $10.1017 / \mathrm{S} 0305741006000415$ 
insecurity, as well as a handful of other problems, it is easy to understand the concerns that policy makers have with regard to social unrest and governance issues. It is therefore no coincidence that policy makers have found the concept of social cohesion - of people sticking together in face of difficulty - an increasingly attractive objective. And, indeed, studies have suggested that a cohesive society facilitates both effective organization for collective action and maintenance of a favourable investment climate. ${ }^{3}$

Whether policy makers regard the idea of social cohesion as a way to avoid potential societal conflicts, improve quality of life or enhance economic performance, clearly they think it is an antidote to a wide range of contemporary problems. Hong Kong faces many of these problems. Globalization, economic recession, and the restructuring and repositioning of the economy drove the unemployment rate to an unprecedented high of 8.8 per cent between May and August $2003^{4}$ and subsequently brought about widespread social discontent. Then in the spring of 2003, just as Hong Kong was finding its way out of the economic slump, the SARS epidemic caught the community unprepared, causing an already vulnerable society more suffering. ${ }^{5}$ The combination of these factors with a general dissatisfaction with the government ${ }^{6}$ and a mounting call for political accountability and democracy ${ }^{7}$ has made achieving social cohesion even more desirable for Hong Kong. In fact, a few years ago the Hong Kong government convened a panel on social cohesion to look into potential threats to social cohesion and ways to build it up. It also set up the Community

3. Lars Osberg (ed.), The Economic Implications of Social Cohesion (Toronto: University of Toronto Press, 2003).

4. http://www.info.gov.hk.censtatd/eng/hkstat/fas/labour/ghs/labour1_index.html.

5. The SARS epidemic first broke out in mid-March 2003. Since it was a new and contagious disease, medical workers were unsure how to treat or contain it, causing an outburst of public panic. By the time the disease was under control at the end of May, more than 1,700 individuals had contracted it, of whom 299 died.

6. According to data collected by the Public Opinion Polling Program at the University of Hong Kong, public support of the chief executive, Tung Chee-hwa, dropped from 64.1 in the first survey after the handover in 1997 to 44.2 in April 2004 (100 indicates complete support; 0 a total lack of support). For a more detailed analysis of the Tung administration, see Lau Siu-kai, "The rise and decline of political support for the Hong Kong Special Administrative Region Government," Government and Opposition, Vol. 34, No. 3 (1999), pp. 352-371; and Sing Ming, "The problem of legitimacy for the post-handover Hong Kong government," International Journal of Public Administration, Vol. 24, No. 9 (2001), pp. 847-867. For an analysis of the tension between civil society and the government of Hong Kong, see Agnes S. Ku, "Negotiating the space of civil autonomy in Hong Kong - power, discourses and dramaturgical representations," The China Quarterly, No. 179 (2004), pp. 647-664.

7. The Public Opinion Polling Program at the University of Hong Kong reported in March 2004 that $60.5 \%$ of respondents agreed to a general election of the next Legislative Council in 2008 (http://hkupop.hku.hk/chinese/popexpress/public_ele/ lcldatatables1.html). It also reported that $62.4 \%$ advocated a general election of the chief executive in 2007 (http://pophku.hku.hk/chinese/chinese/popexpress/public_ele/ ce1/datatables $1 / \mathrm{html})$. 
Investment and Inclusion Fund in 2001 to encourage cross-sectoral co-operation and foster mutual concern among individuals in society. ${ }^{8}$

Despite the prevalence of the notion of social cohesion among many governments and international regimes, it is surprising to discover that it still lacks a commonly agreed definition. Attempts to measure it are scant, and discussions of the forces creating or disrupting it have yet to take place. Given this background, the present article contributes to the literature of social cohesion in three important ways. First, through measuring the level of social cohesion in Hong Kong, it represents one of the earliest attempts to gauge systematically the state of social cohesion in a society. While efforts have been made to provide indicators of social cohesion, ${ }^{9}$ we venture a step further by establishing summary indexes of it. Secondly, as this is the first research dedicated to the state of social cohesion in Hong Kong, the results furnish a baseline for benchmarking in the future. Finally, we undertake to explain the forces that glue society together. In this endeavour, we question the role that formal institutions now play as intermediaries between different sectors of societies and between society and the government. Our research suggests that instead of formal institutions, a different form of "soft" glue may be binding society together.

The next section discusses various definitions of social cohesion and proposes our working definition. The second part of the article presents survey data tracking the state of social cohesion in Hong Kong. The final section attempts to identify the glue that holds Hong Kong society together.

\section{Measuring Social Cohesion}

The concept of social cohesion lacks an agreed definition. ${ }^{10}$ It is not hard to notice that it means different things to different people. At times social cohesion refers to a goal which societies strive to achieve. ${ }^{11}$ At other times it is understood as an ongoing process that

8. In his policy speech in 2001 , the chief executive allocated HK\$300 million to set up the Community Investment and Inclusion Fund in an effort to promote crosssectoral co-operation and build social capital. See www.hwfb.gov.hk/ciif.

9. One of the more comprehensive efforts is provided by the Canadian Council on Social Development for the social cohesion network, the department of Canadian heritage and the department of justice. See Canadian Council on Social Development, "Social cohesion in Canada: possible indicators highlights," Paper SRA-542 (Ottawa: Strategic Research and Analysis Directorate, Department of Heritage, 2000). As impressive as their work is, no attempt is being made to create a social cohesion index.

10. For a comprehensive review of the definitions of social cohesion, see Jeannotte, "Social cohesion," and Caroline Beauvais and Jane Jenson, "Social cohesion: updating the state of the research," CPRN Discussion Paper No. F/22 (Ottawa: Canadian Policy Research Networks, 2002).

11. To Berger-Schmitt, societal cohesion involves two analytically distinct "societal goal dimensions": reduction of disparities and social exclusion, and strengthening of social capital. Regina Berger-Schmitt, "Social cohesion as an aspect of quality of societies: concept and measurement," EuReporting Working Paper No. 14 (Mannheim: Centre for Survey Research and Methodology, 2000), p. 8. 
leads to the creation of socially cohesive societies. ${ }^{12}$ For some, social cohesion is a solution to social and political ills, such as social exclusion, democratic instability and intolerance. ${ }^{13}$ For others, it is partly defined by a set of social and economic conditions. ${ }^{14}$ Because of the various characteristics assigned to social cohesion, its substantive meanings also differ. Broadly speaking, the major features of social cohesion are social solidarity and networks. ${ }^{15}$ Social solidarity encompasses both individual attitudes and structural arrangements; it includes the sense of belonging to a community, equality of opportunity in a market society, recognition of pluralistic values, and the existence of public and private intermediary organizations that bridge different social sectors. Networks chiefly concern social interaction and involvement; they are social capital as Putnam defines it. ${ }^{16}$ A review of the literature suggests that social cohesion is such a nebulous concept that its meaning depends on which study one reads.

The absence of a generally agreed definition has led one scholar to conclude that social cohesion is, at most, a quasi-concept, that is, a concept "flexible enough to allow the meanderings and necessities of political action from day to day." ${ }^{17}$ However, since the concept has been employed quite extensively in various areas and across different countries, it is essential to arrive at a common understanding of it in order to facilitate comparison over time and space. This makes a definition that is narrow in scope and close to ordinary usage

12. The Government of Canada's policy research sub-committee on social cohesion defines social cohesion as "The ongoing process of developing a community of shared values, shared challenges and equal opportunity within Canada, based on a sense of trust, hope and reciprocity among all Canadians." Quoted in Jane Jenson, "Mapping social cohesion: the state of Canadian research," CPRN Study No. Fl03 (Canada: Canadian Policy Research Networks Inc., 1998), p. 4. According to Jenson, the French government has adopted a similarly process-oriented definition.

13. The Council of Europe seems to regard social cohesion as both a means and an end to minimize social exclusion, "the rights deficit," the influence of American culture, as well as the gap between information-rich and information-poor societies. See Jeannotte, "Social cohesion," pp. 87-91.

14. The Canadian Council on Social Development has devised a set of social cohesion indicators for Canada. These can be grouped broadly under two categories: conditions favourable for inclusive social cohesion, including economic conditions, life chances and quality of life; and socially cohesive activities such as willingness to cooperate, and social and civic participation. See Canadian Council on Social Development, "Social cohesion in Canada."

15. Beauvais and Jenson, "Social cohesion: updating the state of the research," p. 23 .

16. Robert Putnam, Bowling Alone: The Collapse and Revival of American Community (New York: Simon \& Schuster, 2000).

17. Paul Bernard, "Social cohesion: a dialectical Critique of a quasi-concept?" SRA-491/CPRN (Ottawa: Strategic Research and Analysis Directorate, Department of Canadian Heritage, 1999/2000), pp. 2-3. A few definitions of social cohesion are indeed suffused with the concept of democratic stability and social well-being. See Jeannotte, "Social cohesion," p. 87; Battaini-Dragoni and Dominioni, "Council of Europe's strategy for social cohesion," p. 6; European Union, First Report on Economic and Social Cohesion 1996 (Luxembourg, 1996), p. 14. 
desirable. ${ }^{18}$ The definition should contain only the essential components of the concept and nothing else. How social cohesion can be maintained, what values are supportive of a cohesive society, under what conditions social cohesion will emerge, what the functions of social cohesion are, and so on, are not core characteristics of social cohesion and should be left out of the definition. In addition, a narrow definition allows us to test whether the phenomenon is related to other socioeconomic and political conditions, such as levels of economic development, literacy rates, income inequality, access to information technology and levels of democratic development. And finally, the term social cohesion is not so technical that it can be used only by social scientists; its definition should therefore not depart much from ordinary usage. Along this spirit, social cohesion is defined in this article as:

A state of affairs concerning both the vertical and the horizontal interactions among member of society as characterized by a set of attitudes and norms that includes trust, a sense of belonging, and the willingness to participate and help, as well as their behavioural manifestations.

Social cohesion thus understood involves two aspects: the objects and the manifestations of cohesion. ${ }^{19}$ The manifestations of cohesion refer to various expressions of cohesion and include both subjective and objective dimensions. While people may feel the presence or absence of cohesion, and even be able to compare levels of cohesion at different times, we argue that a more comprehensive understanding of social cohesion should include its behavioural manifestations. To sense cohesion without actually acting upon it amounts to little more than empty talk that has little impact upon society. Subjective feelings should be supported by objective action when determining the degree of cohesion in any society. Moreover, the object of social cohesion is not to be confined to relations among members of the society, but includes the state. A society united only in its opposition to the government cannot be said to enjoy a strong degree of social cohesion. One must consider both the horizontal aspect of social cohesion - the feelings and behaviour of the society's members - and the vertical aspect, the relations between the members of society and the state. Figure 1 depicts the two dimensions and their four possible combinations.

Cells A and B reflect cohesion among the members of the society. Cell A represents how people feel about their fellow members. It

18. For a detailed discussion of the rationale behind the criteria by which we have defined social cohesion, see Joseph Chan, Benny To and Elaine Chan, "Reconsidering social cohesion," Social Indicators Research, No. 75 (2006), pp. 273-302.

19. We define social cohesion positively, i.e. we try to capture socially cohesive feelings and behaviours. While we are fully aware that not having social cohesion may bring about inequality, exclusion, conflicts and the like, these negative phenomena are indicative of social non-cohesion rather than social cohesion and warrant a separate analysis. A more detailed examination can be found in our "Social cohesion and governance problems in Hong Kong," unpublished manuscript, September 2005. 
Figure 1: Framework of Social Cohesion

\begin{tabular}{|l|c|c|}
\hline & $\begin{array}{l}\text { Subjective component } \\
\text { (attitudes) }\end{array}$ & $\begin{array}{l}\text { Objective component } \\
\text { (behavioural manifestations) }\end{array}$ \\
\hline $\begin{array}{l}\text { Horizontal dimension } \\
\text { (cohesion in civil society) }\end{array}$ & A & B \\
\hline $\begin{array}{l}\text { Vertical dimension } \\
\text { (society-state cohesion) }\end{array}$ & C & D \\
\hline
\end{tabular}

includes whether members of the society can generally trust their fellow members, how willing individuals are to co-operate and help fellow members, their levels of identification with others in the same society, as well as their sense of belonging to the country. Cell B includes all the behavioural manifestations of the feelings expressed in Cell A. It gauges the extent to which feelings of cohesion towards fellow members of the society are put into action. These behaviours include helping friends and neighbours, participation and involvement in groups and associations, voluntary work, and monetary donations. $^{20}$

Cells $\mathrm{C}$ and $\mathrm{D}$ deal with cohesion between the society and the state. Cell $\mathrm{C}$ encompasses the feelings that members of society have towards the government. It measures the level of trust people have in public figures and their confidence in major social and political institutions. Among these institutions are the actual organs of government, the head of the government, political parties, the judicial system, the police and the like. Cell D is the behavioural correspondent for Cell C. It measures whether or not, and how much, people participate in politics as a means of expressing their feelings towards the state in general. Only conventional forms of political participation like voting and political concern are measured. Other forms, most notably protests and demonstrations, are excluded from dimension D because these activities actually signal a breakdown in communication between the government and society. If they continue and become frequent, the relationship between the government and society is likely to be put under pressure, and may eventually bring instability.

We believe that conceptualizing social cohesion in terms of both attitudes and behaviour, as well as among members of society and between society and the government, will give us a more accurate, comprehensive portrait of the level of social cohesion in society. To

20. Horizontal social cohesion is not to be confused with the concept of "social capital," which Putnam refers to as "features of social organization such as networks, norms and trust, that facilitate coordination and cooperation for mutual benefits." Robert D. Putnam, "The prosperous community - social capital and public life," American Prospect, No. 13 (1993), p. 36. Social capital focuses primarily on the individual and the group level, while social cohesion concerns society as a whole. Moreover, it is conceivable for a group to be highly cohesive, and thus rich in social capital, and yet be antagonistic to other groups and thus detrimental to social cohesion. 
leave out any one of these four dimensions obscures the reality and undermines the usefulness of the concept.

\section{The State of Social Cohesion in Hong Kong}

Between 14 August and 11 October 2003 we carried out a two-stage door-to-door survey based on a stratified random sample of the entire territory. The 1,054 respondents aged 18 and above represented a response rate of 71 per cent. The questionnaire contained questions concerning the respondents' feelings and assessments of fellow citizens of Hong Kong and major political figures and institutions. It also asked questions about the respondents' political participation and social involvement. For a general overview of the state of social cohesion in Hong Kong, we created summary indexes representing the four dimensions of social cohesion, with the questions in the questionnaire constituting the bases of the indexes.

Horizontal cohesion. The respondents appeared to feel that on the whole, the people of Hong Kong have a rather strong sense of cohesion. Tables 1 and 2 contain information on the horizontal/ subjective dimension of social cohesion. Table 1 shows that the respondents had a strong sense of belonging to Hong Kong. Over 90 per cent agreed or strongly agreed with the statement that "Hong Kong is my home." This statement referred not only to the fact of their dwelling place, but included an affective undertone. In addition, over 70 per cent claimed to have a strong sense of belonging to Hong Kong. A similar portion of the respondents were proud of being Hongkongers. $^{21}$ These figures led us to the view that members of society have a generally developed sense of togetherness. This view was further strengthened by the readiness of the respondents to help each other out. A much higher proportion of the respondents would rather have their own salaries cut (64.9 per cent) than see colleagues lose their jobs (35.1 per cent). They would also use their spare time to help others (59.5 per cent). Although only just over half of the respondents favoured raising taxes to increase welfare (53.8 per cent), the figure was by no means insignificant when interpreted in the local context. Taking into account that Hong Kong has always taken pride in being a capitalist city and that people still value hard work very

21. Our findings are comparable to previous findings. It has been reported that $64.4 \%$ of respondents claimed to have a strong sense of belonging to Hong Kong and $72.8 \%$ were proud of being Hongkongers; see Lau Siu-kai, "Political culture: traditional or Western," in Lau Siu-kai, Lee Ming-kwan, Wan Po-san and Wong Siu-lun (eds.), Indicators of Social Development: Hong Kong 1997 (Hong Kong: Hong Kong Institute of Asia-Pacific Studies, The Chinese University of Hong Kong, 1999), p. 138. More recently, a survey conducted in 2004 reported that $96 \%$ of respondents claimed that Hong Kong was their home and that $79 \%$ wished their children to regard Hong Kong as their home. Policy 21, The University of Hong Kong and Centre for Civil Society and Governance, Biennial Opinion Survey on Civic Education (2004) Executive Summary. 
Table 1: Percentage Distribution of Various Aspects of Horizontal/ Subjective Social Cohesion

\begin{tabular}{|c|c|c|c|c|c|c|}
\hline & $\begin{array}{c}\text { Highly } \\
\text { disagree }\end{array}$ & Disagree & Agree & $\begin{array}{c}\text { Highly } \\
\text { agree }\end{array}$ & Total (N) & Mean* \\
\hline \multicolumn{7}{|l|}{ General trust } \\
\hline $\begin{array}{l}\text { Don't trust people so } \\
\text { easily in Hong Kong }\end{array}$ & 2.9 & 22.3 & 38.6 & 36.1 & $100.0(1,035)$ & 3.64 \\
\hline $\begin{array}{l}\text { Hongkongese likes to } \\
\text { take advantage of } \\
\text { others }\end{array}$ & 7.3 & 35.7 & 40.4 & 16.6 & $100.0(1,023)$ & 4.92 \\
\hline \multicolumn{7}{|l|}{ Willingness to help } \\
\hline $\begin{array}{l}\text { Use spare time to help } \\
\text { others }\end{array}$ & 7.1 & 33.4 & 43.2 & 16.3 & $100.0(1,018)$ & 6.16 \\
\hline $\begin{array}{l}\text { Pay higher tax to } \\
\text { increase welfare }\end{array}$ & 15.6 & 30.7 & 39.0 & 14.8 & $100.0(962)$ & 5.66 \\
\hline $\begin{array}{c}\text { Cut salary than have } \\
\text { colleagues laid off }\end{array}$ & 9.1 & 26.0 & 42.2 & 22.7 & $100.0(957)$ & 6.45 \\
\hline \multicolumn{7}{|l|}{$\begin{array}{l}\text { Sense of belonging to } \\
\quad H K\end{array}$} \\
\hline $\begin{array}{l}\text { Proud of being } \\
\text { Hongkongese }\end{array}$ & 4.7 & 25.0 & 48.2 & 22.1 & $100.0(1,021)$ & 6.70 \\
\hline $\begin{array}{l}\text { Hong Kong is my } \\
\text { home }\end{array}$ & 1.7 & 7.4 & 42.2 & 48.5 & $100.0(1,026)$ & 8.18 \\
\hline Sense of belonging & 2.1 & 14.5 & 58.7 & 24.8 & $100.0(1,013)$ & 7.26 \\
\hline
\end{tabular}

Note:

*Mean scores range from 1 to 10 with 1 referring to highly disagree, and 10, highly agree. Scores above the mid-point 5.5 indicate positive feelings.

much $^{22}$ and believe that working hard will eventually brings success, ${ }^{23}$ the proportion agreeing to increase welfare by raising taxes is quite remarkable.

If the respondents exhibited a relatively strong sense of belonging to Hong Kong and were willing to help other Hongkongers, they did not have a correspondingly strong degree of trust in their fellow citizens. Only about a quarter of the respondents thought that they could trust fellow members of society, and 57 per cent believed that the people of Hong Kong liked to take advantage of others. The meaning of both figures leaps out if they are compared with those of other countries. In the United States, 34 per cent believed that most people could be

22. When asked whether "hard working" describes a value common to the people of Hong Kong, our respondents rated it 8.21 on a scale of 1 to 10 (1 referring to "definitely not" and 10 "definitely yes"). It is the second highest score among 12 value items.

23. $46.4 \%$ agreed and $30.2 \%$ strongly agreed that individuals who work hard will eventually make it in Hong Kong. 


\section{Table 2: Mean Scores of Willingness to Co-operate/Trust Various}

\section{Groups}

\begin{tabular}{lcc}
\hline & $\begin{array}{c}\text { Willingness to } \\
\text { co-operate* }\end{array}$ & Willingness to trust \\
\hline From lower social stratum & $7.41(1)$ & $6.47(1)$ \\
From higher social stratum & $7.07(2)$ & $6.38(2)$ \\
Former CSSA recipients & $6.95(3)$ & $6.10(3)$ \\
New immigrants from mainland & $6.70(4)$ & $5.85(5)$ \\
Europeans/Americans & $6.33(5)$ & $5.89(4)$ \\
Different political ideologies & $5.60(6)$ & $5.17(7)$ \\
Homosexuals & $5.35(7)$ & $5.34(6)$ \\
Indians/Pakistanis & $5.33(8)$ & $4.82(8)$ \\
\hline
\end{tabular}

Note:

*Mean scores range from 1 to 10,1 indicating extremely unwilling to co-operate/ trust, and 10, extremely willing. Scores above the 5.5 mid-point mean positive feelings of confidence.

trusted, ${ }^{24}$ compared with 39 per cent in Australia, ${ }^{25} 44$ per cent in the United Kingdom, ${ }^{26}$ and 67 per cent in Sweden. ${ }^{27}$ Thus general trust was not as pervasive in Hong Kong as in these Western countries. ${ }^{28}$

Fortunately for social cohesion, the respondents exhibited more positive views with regard to groups which are commonly thought to create cleavages in society, be they along socioeconomic, political, ethnic or sexual lines. As indicated in Table 2, socioeconomic factors, which have often been a strongly divisive force elsewhere, do not figure much in the Hong Kong context. Probably because there is a great degree of social mobility and people generally believe that one's ability and diligence are usually rewarded, class conflict is very rare. In fact, socioeconomic factors are almost irrelevant to the cultivation of trust and co-operation. The three groups of individuals that the respondents most trusted or were willing to work with were made up of individuals coming from a lower social stratum, individuals coming

24. Robert Wuthnow, "United States: bridging the privileged and the marginalized?" in Robert D. Putnam (ed.), Democracies in Flux: The Evolution of Social Capital in Contemporary Society (Oxford: Oxford University Press, 2002), p. 71.

25. Data come from the World Values Study 1995, cited in Eva Cox, "Australia: making the lucky country," in Putnam, Democracies in Flux, p. 349.

26. Data come from the World Values Survey 1990, cited in Peter A. Hall, "Social capital in Britain," British Journal of Political Science, No. 29 (1999), p. 432.

27. Data collected in 1997 and cited in Bo Rothstein, "Sweden: social capital in the social democratic state," in Putnam, Democracies in Flux, p. 320.

28. Respondents in another survey reported trust in their family and in people that they know, such as friends, relatives, neighbours and colleagues, as well as professionals such as doctors, judges, professors and lawyers. They are, however, very suspicious of people that they do not know, which reflects a low level of general trust. Lau Siu-kai, "Attitudes towards political and social authorities," in Lau Siu-kai, Lee Ming-Kwan, Wan Po-san and Wong Siu-lun (eds.) Indicators of Social Development: Hong Kong 1999 (Hong Kong: Hong Kong Institute of Asia-Pacific Studies, The Chinese University of Hong Kong, 2001), p. 79. 
Table 3: Percentage Distribution of Horizontal/Objective Activities

\begin{tabular}{llc}
\hline & Percentages & $(n)$ \\
\hline Helping friends and neighbours & & \\
Domestic work & 40.6 & $(1,037)$ \\
Financial assistance & 26.9 & $(1,034)$ \\
Emotional support & 70.8 & $(1,043)$ \\
Volunteering & & \\
Not a volunteer & 80.6 & $(1,047)$ \\
Among the volunteers & & \\
$\quad$ Weekly & 15.3 & $(203)$ \\
$\quad$ Monthly & 16.3 & $(203)$ \\
$\quad$ 1-2 times a year & 38.9 & $(203)$ \\
Monetary donations & & \\
No donation made & 40.7 & $(1,054)$ \\
Among those donated & & \\
$\quad$ \$100 or less & 40.5 & $(625)$ \\
$\quad$ \$101-500 & 30.2 & $(625)$ \\
Membership in organizations & & \\
Non-joiners & 57.6 & $(1,054)$ \\
Among joiners: & & \\
$\quad$ Taking part in organized events & 84.5 & $(450)$ \\
$\quad$ Being a volunteer & 16.6 & $(450)$ \\
$\quad$ Mrganizing activities & 10.8 & $(450)$ \\
& 10.4 & $(450)$ \\
\hline
\end{tabular}

from a higher social stratum and former welfare (CSSA) recipients. Nevertheless, the findings in no way suggest that Hong Kong society is all-inclusive. The respondents were less willing to trust and work with Indians or Pakistanis and homosexuals. In addition, they did not trust people embracing a political view different from their own.

In spite of feeling cohesive, respondents did not act as cohesively. Table 3 shows self-reported helping behaviour was not common. About 40 per cent reported they had helped friends or neighbours in domestic work such as looking after young children or the elderly, picking up groceries, cooking meals and so forth, and one-fourth had given some form of financial assistance to friends or neighbours in the past year. The most common helping behaviour turned out to be lending emotional support to friends and neighbours. The majority of the respondents ( 70.8 per cent) listened to friends and neighbours or offered advice when such emotional support was asked for.

Volunteering and making monetary donations were not particularly impressive either. Similar to other findings about giving and volunteering in Hong Kong, ${ }^{29}$ only about 20 per cent of the

29. A telephone survey conducted by The Hong Kong Federation of Youth Groups reported that $23.1 \%$ of all respondents took part in organized volunteer work and $62.7 \%$ have made donations through organizations. The Hongkong Federation of Youth Groups. A Study on Social Capital with Regard to Giving, Volunteering and 
respondents had been a volunteer in the past year. This is low compared with similar figures in the United States (44 per cent), ${ }^{30}$ the United Kingdom (48 per cent) ${ }^{31}$ and Canada (27 per cent). ${ }^{32} \mathrm{~A}$ considerable number of those who volunteered offered their services only infrequently; only 15.3 per cent volunteered once a week and close to 40 per cent just once or twice a year. As far as monetary donations are concerned, 40.7 per cent made no donations in the last year. Among those who gave, 70.7 per cent gave HK\$500 (about US\$64) or less in the entire year. Monetary donations were much higher in the United States and Canada; 89 per cent of all households in the United States contributed, with the average annual donation per household being US\$1,620. ${ }^{33}$ In Canada, 78 per cent claimed to have made monetary donations. ${ }^{34}$

Social involvement, another aspect of horizontal/objective social cohesion, was again not strong. In line with previous findings on social capital and engagement in Hong Kong, ${ }^{35}$ the respondents were not keen to join organizations; about four in ten (42.4 per cent) claimed to belong to at least one group. According to the World Values Survey conducted in the early 1990s, the corresponding figures of social membership were 82 per cent in the United States, 85 per cent in the Netherlands, 67 per cent in West Germany, 65 per cent in Canada and 54 per cent in the United Kingdom. ${ }^{36}$ Moreover, those who joined organizations in Hong Kong tended to be passive

footnote continued

Participating (Hong Kong: The Hongkong Federation of Youth Groups, 2002), pp. 18, 30. A similar finding on organized volunteering $(22.4 \%)$ is reported in a telephone survey commissioned by the Agency for Volunteer Service. See Chung Ting-yiu Robert, Pang Ka-lai Karie and Law Wai-yan Candy, Study on Public's Reception and Perception of Volunteer Services (Hong Kong: The University of Hong Kong Public Opinion Programme, 2002), p.55.

30. Adults aged 21 and above only. Independent Sector, Giving and Volunteering in the United States (2001); see http://www.independentsector.org/PDFs/GV01keyfind. pfd. htm.

31. Institute of Voluntary Research, UK, http://www.ivr.org.uk/nationalsurvey.

32. As a percentage of population aged 15 or above. From 2000 National Survey of Giving, Volunteering and Participating, http://www.givingandvolunteering.ca.

33. Household data, Independent Sector, Giving and Volunteering in the United States.

34. Data come from the 1997 National Survey of Giving, Volunteering and Participating. Quoted in Andrew Jackson et al., "Social cohesion in Canada: possible indications (HIGHLIGHTS)," SRA-542 (Ottawa: Strategic Research and Analysis, 2000), p.72.

35. A telephone survey in 2001 found that $24.2 \%$ of the respondents claimed to have joined at least one organization. The Hong Kong Federation of Youth Groups, $A$ Study on Social Capital with Regard to Giving, Volunteering and Participating (Hong Kong: The Hongkong Federation of Youth Groups, 2002), p. 46. However, when compared with membership in the last 20 years, the overall trend seems to be on the rise. Ian Holliday and Waikeung Tam, "Social capital in Hong Kong." East Asia: An International Quarterly, Vol. 19. Nos. 1/2, pp. 144-170.

36. Everett Carll Ladd, The Ladd Report (New York: The Free Press, 1999), p. 133. 
participants, for an overwhelming majority ( 84.5 per cent) enjoyed activities being organized for them, and only about one-tenth took part in making those activities possible for others.

Our findings in the two horizontal dimensions of social cohesion show that inhabitants of Hong Kong feel cohesive but do not act in an entirely cohesive way. Although the respondents showed considerable attachment to society and displayed quite an inclusive attitude towards people from different socioeconomic strata, participatory social involvement fell short of people's proclaimed affection for society. As demonstrated by both the breadth and depth of reported helping behaviour - voluntarism and donations - as well as engagement in organized groups, the respondents' level of social involvement tended to be on the low end.

Vertical social cohesion. Dimension C (vertical/subjective) is concerned with how society feels about the government. Consistent with most other findings on Hong Kong people's political confidence, ${ }^{37}$ the mean scores of confidence reported in Table 4 show that the people have lost trust in political institutions in general and the executive branch in particular. Scores above the midpoint, 5.5, can be regarded as indicating confidence. Neither the chief executive (4.79),

\section{Table 4: Mean Scores of Confidence in Various Political Institutions and Systems of the Administration of Justice}

\begin{tabular}{llc}
\hline & Mean* & Rank \\
\hline Political institutions & & \\
Directly elected LegCo councillors & 5.66 & 1 \\
Functionally elected LegCo councillors & 5.35 & 2 \\
Senior civil servants & 5.22 & 3 \\
Executive council & 4.90 & 4 \\
Chief executive & 4.79 & 5 \\
Principal officials & 4.23 & 6 \\
Administration of justice & & \\
ICAC & 8.15 & 1 \\
Ombudsman & 7.47 & 2 \\
Police & 7.08 & 3 \\
Judicial system & 6.75 & 4 \\
\hline
\end{tabular}

Note:

* Range from 1 to 10,1 indicating an absence of confidence, and 10 extremely confident. Scores above the 5.5 mid-point indicate positive feelings of confidence.

37. Timothy Ka-ying Wong, "The changing public perception of the chief executive," in Lau Siu-kai (ed.), The First Tung Chee-hwa Administration: The First Five Years of the Hong Kong Special Administration Region (Hong Kong: The Chinese University Press, 2002). 
nor his appointed executive council (4.90), nor his creation, the principal official system (4.23) was able to secure the trust of respondents. Senior government officials also failed to gain the respondents' confidence (5.22). Legislative councillors fared a little better. Although functionally elected legislative councillors failed by a small margin (5.35), the geographically elected councillors managed to get a positive score (5.66). Respondents' lack of confidence in political institutions is put in bold relief when we juxtapose the scores awarded to political institutions with those awarded to institutions upholding justice in society. The scores of the justice institutions were well above 5.5. The Independent Commission Against Corruption (ICAC) topped all other justice-maintenance institutions, receiving a score of 8.15 out of a possible 10. It was followed by the ombudsman (7.47), the police (7.08) and the judicial system (6.75).

That the citizens bestowed higher levels of confidence on the judicial system than the government is not exactly alarming or new, ${ }^{38}$ and it is by no means unique to Hong Kong. In the United Kingdom, 53 per cent of the people indicated trust in the judiciary, compared with 43 per cent who trusted the government. ${ }^{39}$ The corresponding figures for Australia were 35 per cent and 26 per cent respectively. ${ }^{40}$ What is interesting about the case of Hong Kong is that, in line with established democracies where there is a clear division between the executive, the legislative and the judicial systems, respondents to our survey obviously made a distinction between individuals or systems responsible for making or implementing public policy and those that uphold justice. Furthermore, the differential dispels any suspicion that the respondents distrust public institutions indiscriminately.

Dimension D tries to capture cohesive activities between the society and state, the most basic of which, we believe, indicate concern with politics and voting in elections. Paying attention to major happenings in society, the work of the government and current debates are the first steps in political involvement. Casting one's vote in political elections is fundamental to fulfilling one's civic responsibility. We therefore used these two aspects to delineate vertical cohesive behaviour between society and the government.

As expected, ${ }^{41}$ Table 5 reveals that the respondents were concerned about politics. A vast majority ( 80.9 per cent) got news every day by

38. A survey conducted in 1999 reported that people have higher confidence in the judiciary system, the police and the ICAC than other public institutions. Ho Kwokleung. "Popular support for effective governance," in Lau, Lee, Wan and Wong, Indicators of Social Development: Hong Kong 1999, p. 45.

39. Data collected in 2001. Trust in Public Institutions, p.12. A research study by MORI Social Research Institute on behalf of the Audit Commission, UK, http://www. mori.com/sri/pdf/final/pdf.

40. Data collected in 1995. Neal Ryan, "Public confidence in the public sector," discussion paper prepared for the Office of the Auditor General of Western Australia (2000), http://www.audit.wa.gov.au/pubs/public_confidence.pdf.

41. Lau Siu-kai and Kuan Hsin-chi, "The attentive spectators: political participation of the Hong Kong Chinese,' Journal of Northeast Asian Studies, Vol. 14, No. 1 (1995), pp. 3-24. 
Table 5: Percentage Distribution of Indicators of Political Concern

\begin{tabular}{lcccc}
\hline & News reports & $\begin{array}{c}\text { Discuss with } \\
\text { friends }\end{array}$ & $\begin{array}{c}\text { Current affairs } \\
\text { programmes }\end{array}$ & $\begin{array}{c}\text { Radio } \\
\text { phone-ins }\end{array}$ \\
\hline Never & 3.1 & 16.0 & 6.1 & 32.9 \\
Seldom & 11.8 & 28.2 & 15.5 & 26.2 \\
Sometimes & 4.2 & 42.2 & 45.3 & 24.3 \\
Often & 80.9 & 13.5 & 33.1 & 16.0 \\
Total & 100.0 & 100.0 & 100.0 & 100.0 \\
(n) & $(1,044)$ & $(1,049)$ & $(1,048)$ & $(1,042)$ \\
\hline
\end{tabular}

reading newspapers or watching televised news reports; about the same proportion (78.4 per cent) also watched current affairs programmes on television either sometimes or often. Discussing current affairs with friends was not as prevalent (55.7 per cent sometimes or frequently). The proportion of those who listened to radio-commentary and phone-in programmes was even lower (40.9 per cent sometimes and often). Nevertheless, the bulk of the respondents did receive news almost on a daily basis.

Self-reported voting behaviour was fairly high (Table 6). More than one-third of the respondents reported voting in every single Legislative Council (LegCo) (35.6 per cent) and district board/council ( 37.0 per cent) election. If we add to these figures the percentage of those who usually cast their votes but not every single time, the proportion of regular and frequent voters increases to half of the respondents for elections of both LegCo (51.2 per cent) and the district boards/councils (50.8 per cent). Judging from the respondents' concern with politics and their voting behaviour, the society appears to manifest a high level of vertical cohesive activities.

Summary indexes of the state of social cohesion in Hong Kong. To provide an overall depiction of the state of social cohesion in Hong Kong, we constructed eight summary indexes, two for each of the four dimensions of social cohesion, using the following general procedure.

Table 6: Percentage Distribution of Past Voting Behaviour

\begin{tabular}{lcc}
\hline & Legislative Council & District \\
& 28.7 & 25.3 \\
Never & 9.0 & 10.5 \\
Seldom & 11.1 & 13.4 \\
Sometimes & 15.6 & 13.8 \\
Often & 35.6 & 37.0 \\
Every time & 100.0 & 100.0 \\
Total & $(655)$ & $(659)$ \\
(n) & & \\
\hline
\end{tabular}


First, we carried out a reliability test for all the questions that appeared to represent an aspect of a dimension. Questions that substantially weakened the overall Cronbach's alpha were removed. Next, we performed an exploratory factor analysis (principal component analysis) on all the remaining items of the same dimension. We created an index by summing up all the questions that had been grouped under the same component. The results of the factor analysis are summed up in Table 7. The scores of all the indexes were standardized to range from a low of 1 to a high of 10, with 5.5 being the midpoint. Scores above 5.5 indicated a feeling or action in the direction of cohesion. The eight indexes and their content are summarized in Table 8 .

Three out of the eight indexes obtained scores below 5.5, indicating that respondents did not feel or act cohesively in these aspects. Both indexes under dimension B (horizontal/objective) failed to reach the mid point. This suggests that the respondents, despite having developed an attachment to society, are not acting out their commitment. They do not help their friends very much and are involved only minimally in social groups and volunteering. The other index below the midpoint is that for confidence in political institutions. As shown in Table 4, respondents simply do not have confidence in the executive branch of the government.

In brief, according to our classification, the state of social cohesion in Hong Kong is rather mixed. While the respondents distrust the executive branch of the government, they have a relatively high degree of confidence in the justice institutions. As citizens they act cohesively in that they care about politics and vote regularly in various elections. As members of society, the respondents display positive attitudes towards cohesion, but seldom take action to promote it.

\section{Plausible Mechanisms of Social Cohesion in Hong Kong}

According to our definition of social cohesion, Hong Kong is not highly cohesive. Socially, Hongkongers do not act cohesively, and politically they do not feel cohesively. Despite these findings, we asked the respondents how they felt about cohesion among members of society and between society and the government. The respondents generally felt that horizontal cohesion was much stronger than vertical cohesion. They awarded a mere 4.44 score to vertical cohesion while horizontal cohesion received a score of 6.14 . The scores indicate that the respondents feel that the relationship between society and the government is much poorer than that among members of society.

This apparent paradox - the co-existence of a relatively low level of membership in voluntary association and volunteering and the presence of subjective social cohesion - leads to the following questions. If participation in formal organizations is low, what has brought about people's positive attitudes that constitute horizontal social cohesion? 
Table 7: Factor Loadings of Items on the Four Dimensions of Social Cohesion

\begin{tabular}{|c|c|c|c|}
\hline Social cohesion dimenions & Index & Index & $\begin{array}{l}\text { Variance } \\
\text { explained }\end{array}$ \\
\hline Horizontallsubjective & Reciprocity & Commitment & $59.5 \%$ \\
\hline General trust & .218 & -.343 & \\
\hline Particularized trust & .860 & .051 & \\
\hline $\begin{array}{l}\text { Willingness to co-operate with } \\
\text { socio-economic groups }\end{array}$ & .828 & .132 & \\
\hline $\begin{array}{l}\text { Willingness to co-operate with } \\
\text { other groups }\end{array}$ & .882 & -.054 & \\
\hline Willingness to help & .149 & .732 & \\
\hline Sense of belonging & .129 & .778 & \\
\hline Horizontallobjective & $\begin{array}{c}\text { Social } \\
\text { involvement }\end{array}$ & Helping behaviour & $54.7 \%$ \\
\hline Helping household work & .165 & .680 & \\
\hline Lending money & -.097 & .768 & \\
\hline Giving emotional support & .311 & .669 & \\
\hline Membership in organizations & .778 & .121 & \\
\hline Donation to charities & .656 & .235 & \\
\hline Volunteering & .727 & -.018 & \\
\hline Vertical/subjective & $\begin{array}{l}\text { Trust in political } \\
\text { institution }\end{array}$ & $\begin{array}{l}\text { Trust in justice } \\
\text { administration }\end{array}$ & $69.36 \%$ \\
\hline Chief executive & .878 & .069 & \\
\hline Executive council & .900 & .151 & \\
\hline Principal official system & .888 & .087 & \\
\hline Senior civil officials & .819 & .280 & \\
\hline $\begin{array}{l}\text { Popularly elected LegCo } \\
\text { members }\end{array}$ & .531 & .418 & \\
\hline $\begin{array}{l}\text { Functionally elected LegCo } \\
\text { members }\end{array}$ & .694 & .319 & \\
\hline Judicial system & .257 & .737 & \\
\hline Police & .215 & .811 & \\
\hline ICAC & .109 & .866 & \\
\hline Ombudsman & .101 & .811 & \\
\hline Verticallobjective & Political concern & $\begin{array}{l}\text { Political } \\
\text { participation }\end{array}$ & $58.35 \%$ \\
\hline Voted in LegCo & -.131 & .879 & \\
\hline Voted in district council & -.100 & .885 & \\
\hline Watched news & .549 & -.221 & \\
\hline Discussed politics & .762 & .082 & \\
\hline Watched current affairs & .787 & -.065 & \\
\hline Listened to radio & .538 & -.258 & \\
\hline
\end{tabular}


Table 8: Social Cohesion Indexes

\begin{tabular}{|c|c|c|}
\hline Dimension & Content & Mean score \\
\hline \multicolumn{3}{|l|}{ Dimension A } \\
\hline Reciprocity index & $\begin{array}{ll}\text { - } & \text { General trust } \\
\text { - } & \text { Willingness to co-operate } \\
\text { - Willingness to trust }\end{array}$ & 5.89 \\
\hline Commitment index & $\begin{array}{l}\text { - Sense of belonging } \\
\text { Willingness to forego individual } \\
\text { interests for the common good }\end{array}$ & 6.68 \\
\hline \multicolumn{3}{|l|}{ Dimension B } \\
\hline Helping behaviour index & $\begin{array}{l}\text { Helping friends and neighbour with } \\
\text { household work } \\
\text { - Helping friends and neighbour } \\
\text { financially } \\
\text { - Helping friends and neighbour } \\
\text { emotionally }\end{array}$ & 3.54 \\
\hline Social involvement index & $\begin{array}{l}\text { - Membership in organizations } \\
\text { - Number of charities to which the } \\
\text { respondents have donated } \\
\text { - Volunteering }\end{array}$ & 2.00 \\
\hline \multicolumn{3}{|l|}{ Dimension $C$} \\
\hline $\begin{array}{l}\text { Confidence in political } \\
\text { institutions index }\end{array}$ & $\begin{array}{l}\text { - Confidence in the chief executive } \\
\text { - Confidence in the executive council } \\
\text { - Confidence in the principal official } \\
\text { system } \\
\text { - Confidence in senior civil servants } \\
\text { - Confidence in directly elected LegCo } \\
\text { members } \\
\text { - Confidence in functionally elected } \\
\text { LegCo members }\end{array}$ & 4.96 \\
\hline $\begin{array}{l}\text { Confidence in the } \\
\text { administration of } \\
\text { justice index }\end{array}$ & $\begin{array}{l}\text { - Confidence in the judicial system } \\
\text { - Confidence in the police } \\
\text { - Confidence in the ICAC } \\
\text { - Confidence in the Ombudsman }\end{array}$ & 7.33 \\
\hline \multicolumn{3}{|l|}{ Dimension D } \\
\hline Political concern index & $\begin{array}{l}\text { - Watch/read news reports } \\
\text { - Discussion of politics with friends } \\
\text { - Watch current affairs programmes on } \\
\text { TV } \\
\text { - Listen to news/current affairs phone- } \\
\text { in programmes }\end{array}$ & 6.60 \\
\hline $\begin{array}{l}\text { Political participation } \\
\text { index }\end{array}$ & $\begin{array}{l}\text { Voting behaviour in past LegCo } \\
\text { elections } \\
\text { - Voting behaviour in past district } \\
\text { boards/council elections }\end{array}$ & 6.02 \\
\hline
\end{tabular}


The question of horizontal cohesion is particularly puzzling, for social participation and feeling cohesive should go hand-in-hand. Joining organizations and taking part in community activities are essential in the creation of social capital, that is, the "connections among individuals - social networks and the norms of reciprocity and trustworthiness that arise from them." ${ }^{42}$ People engaging in face-toface interactions are likely to develop mutual trust and reciprocity. It is also easier for them to get together and act collectively. Putnam has shown that societies rich in social capital are safer, healthier, happier, more tolerable and, in general, economically and civically more equitable. ${ }^{43}$ Following Putnam, we take social capital to be part and parcel of objective horizontal social cohesion; a society with abundant social capital should also have a high degree of horizontal social cohesion. ${ }^{44}$ Yet despite being socially inactive, and therefore deficient in social capital, Hongkongers still feel some cohesiveness. In other words, the lack of social involvement in the sense of joining organizations has not undermined the feeling of cohesion in Hong Kong.

Are there alternative forms of association, then, that have more or less the same effect as joining formal organizations? How can the feeling of social cohesion be achieved in Hong Kong without the mediation of traditional institutions? The literature on civic engagement has pointed to three alternative forms of engagement: lending support to advocacy groups, ${ }^{45}$ joining informal support groups ${ }^{46}$ and maintaining contact with significant others ${ }^{47}$ - people who matter to

\section{Putnam, Bowling Along, pp. 296-349.}

43. Ibid.

44. Social capital makes up part of our definition of social cohesion, but there are others who use the two concepts synonymously, such as The World Bank. See http:// www1.worldbank.org/prem/poverty/scapital/home.htm.

45. The burgeoning of advocacy groups in the United States has led one scholar to call it "the advocacy explosion." See Theda Skocpol, "Advocates without members: the recent transformation of American civic life," in Theda Skocpol and Morris P. Fiorina (eds.), Civic Engagement in American Democracy (Washington DC: Brookings Institution Press and New York: Russell Sage Foundation, 1999). It has also been shown that advocacy groups more easily gained access to testify in congressional hearings and got media coverage about their work than traditional organizations. Jeffrey M. Berry, "The rise of citizen groups," in ibid. At the community level, activists focus on local issues that affect their daily lives, and their involvements are mostly issue-based and ad-hoc. Sidney Tarrow, "Mad cows and social activists: contentious politics in the trilateral democracies," in Susan J. Pharr and Robert D. Putnam (eds.), Disaffected Democracies: What's Troubling the Trilateral Countries? (Princeton, NJ: Princeton University Press, 2000).

46. The small-group movement is flourishing in the United States, where $40 \%$ of all Americans belong to some small group that meets regularly. Popular small groups include Sunday school classes, bible study groups and self-help groups. Robert Wuthnow, Sharing the Journey: Support Groups and America's New Quest for Community (New York: The Free Press, 1994), pp. 47, 65 and 76.

47. Wuthnow's study also found that among the $60 \%$ of Americans who do not belong to any small groups, over half have a circle of friends from who they can get help if necessary. Wuthnow, Sharing the Journey, p. 183. His other study reported that most Americans, especially women, enjoy the support of families and friends. Robert Wuthnow, Loose Connections: Joining Together in America's Fragmented Communities (Cambridge, MA: Harvard University Press, 1998), pp. 204-205. 
us and whom we can rely on in times of need. Membership structure and modes of involvement are very different in all three from those of formal organizations. However, evidence shows that these forms of activity are popular and effective in achieving the goals they set for themselves, and they also appear highly compatible with the structure of modern life.

These alternative forms of association may be taking place in Hong Kong. Although the citizens of Hong Kong are not keen to join formal organizations, they may be lending their support to advocacy groups. Table 9 reports on the extent to which various forces were deemed to be strengthening or undermining social cohesion. If we look at the forces relevant to horizontal social cohesion - business leaders/chambers of commerce, labour leaders/unions, the mass media, professional associations, religious leaders/organizations and academics, only business leaders/chambers of commerce were deemed to undermine social cohesion slightly. The other five groups were thought to strengthen social cohesion.

It is not unexpected for traditional organizations such as religious organizations (5.83) and labour unions (5.74) to be seen as enhancing social cohesion. It is, however, interesting for professional organizations and academics to be held in such high regard. The scores awarded to professional organizations (6.28) and academics (6.59) are higher than those given to traditional groups. ${ }^{48}$ It seems that the respondents not only trust academics and professional groups, but they also appreciate the efforts of these groups in promoting social cohesion. In Hong Kong, certain prominent advocacy groups are made up of professionals and academics. Examples that come readily to mind are the Article 23 Concern Group (23 tiao guanzhuzu 23條關 注組) and the Hong Kong Democratic Development Network (Xianggang minzhu fazhan wangluo 香港民主發展網絡) (DDN). The former is made up of lawyers and legal scholars and the latter, headed by two clergy, is composed mainly of academics and professionals (lawyers, doctors, social workers and so on). Strictly speaking, both the Article 23 Concern Group and the DDN are not professional organizations, but their members use their professional expertise to direct public discussions. Both groups are respected for their professional knowledge and could therefore be regarded by the respondents as professional groups. Both organizations manifest the major characteristics of advocacy groups in the United States: restrictive and small membership, and expertise in the area of their concern.

The work of the Article 23 Concern Group serves as a good illustration. Article 23 of the Basic Law is about national security. In an effort to write the provisions of Article 23 into the law of Hong

48. It was found that more people indicated trust in doctors, judges, professors, lawyers and journalists than trade unions and religious leaders. Lau Siu-kai, "Attitudes towards political and social authorities," p. 79. 


\section{Table 9: Perceived Effects of Various Forces on Social Cohesion}

\begin{tabular}{|c|c|c|c|c|c|}
\hline \multicolumn{3}{|c|}{ Vertical cohesion forces } & \multicolumn{3}{|c|}{ Horizontal cohesion forces } \\
\hline & Mean & (n) & & Mean & (n) \\
\hline $\begin{array}{l}\text { Central } \\
\text { government }\end{array}$ & 5.95 & (973) & $\begin{array}{l}\text { Business tycoons/ } \\
\text { chambers }\end{array}$ & 5.26 & (941) \\
\hline Chief executive & 4.85 & $(988)$ & Labour unions/leaders & 5.74 & $(925)$ \\
\hline Principal officials & 4.90 & $(956)$ & Police & 6.73 & (976) \\
\hline Public policy & 4.75 & $(965)$ & Mass media & 5.89 & $(985)$ \\
\hline Style of governance & 4.59 & $(963)$ & $\begin{array}{l}\text { Professional } \\
\text { associations }\end{array}$ & 6.28 & (911) \\
\hline $\begin{array}{l}\text { Pro-democracy } \\
\text { groups }\end{array}$ & 5.26 & $(928)$ & $\begin{array}{l}\text { Religious } \\
\text { organizations/ } \\
\text { leaders }\end{array}$ & 5.83 & (933) \\
\hline Pro-China groups & 4.70 & (910) & Academics & 6.59 & $(965)$ \\
\hline
\end{tabular}

Kong, the government sent the National Security Bill to the legislature for passage in the spring of 2003. Without expert decoding, it would have been almost impossible for ordinary citizens to understand the dire implications of the bill. Seeing this, a group of lawyers and legal scholars got together and called themselves the Article 23 Concern Group. During the public consultation period, the group deciphered many of the bill's legal terms and explained its implications. It was the driving force in opposing the bill and was therefore widely seen as a protector of civil rights and liberties. The group has gained tremendous popularity and respect from society.

The Article 23 Concern Group is representative of public-serving advocacy groups for several reasons. First, formal organizational structure is irrelevant. Secondly, its membership is limited and extremely small. Thirdly, it contributes its expertise to society. Finally, it is public-serving. Its aim is not to promote the benefits of its members nor to bridge different organizations, but to serve society as a whole. In general, advocacy groups disseminate information, direct public opinion and act as intermediaries between society and the government. In the context of Hong Kong, the functions normally performed by advocacy groups elsewhere such as the United States are also carried out by professional organizations, academics, experts and the media. Most of our respondents regarded these advocacy groups as enhancing social cohesion in Hong Kong.

It is therefore possible that without personally joining organizations or engaging in volunteering, the respondents participate vicariously through the work of some highly publicized groups. People are not cut off from the rest of society, but apparently do not carry out their civic participation in the medium of formal institutions. This is plainly evident in the astounding response to the 1 July 2003 anti-Article 23 protest, where an estimated 500,000 Hongkongers took to the 
streets ${ }^{49}$ and in the election of four of the Article 23 Concern Group's core members to the 2004 Legislative Council. ${ }^{50}$

In addition to supporting advocacy groups, people may involve themselves in society in a variety of ways, such as in forming local, small and informal groups. We do not have data to show the prevalence of small groups in Hong Kong; nor do we know their role in the creation of social capital. But our survey does suggest this is an area worth investigating, for 59.4 per cent of the respondents said they regularly took part in hobby group gatherings or pursued a hobby with friends. Among this group, 39.8 per cent met as regularly as every week and a further 27.7 per cent met monthly. Unfortunately, we lack data to show the extent to which participation in hobby groups provides mutual support to group members, or how much, if at all, these groups are involved in public affairs. If small, informal groups do create social capital, a point that Robert Wuthnow has so vividly argued, horizontal objective social cohesion in Hong Kong may be substantially greater than our survey figures indicate.

Maintaining close contact with significant others provides the foundation for civic engagement. People who do not have families or friends to whom they can turn are more alienated and more likely to be cut off from society. Families and friends have traditionally been a vital element in Hong Kong society, whose dominant cultural code was once described as "utilitarian familism." 51 Most Hongkongers still appear to maintain a good relationship with family members. When asked to evaluate how close they were with family members, the respondents in our survey were very positive, awarding 8.27 to their partners, 8.51 to their children, 8.18 to their parents and 7.97 to their siblings. An overwhelming majority (85.4 per cent) reported having friends whom they could trust. These figures suggest again that while Hongkongers are not keen organization joiners they are by no means alienated from society. Their connection with society-at-large may be channelled via personal connections rather than formal institutions.

We suspect that this is why our respondents felt socially cohesive but did not behave accordingly. Hong Kong is a busy, modern society, with a vibrant mass media and easy access to the internet. People may prefer lending support to advocacy groups and forming small, informal groups to membership in formal organizations. Small,

49. It can be argued that opposing Article 23 was not the only reason for people to take to the streets. However, it was the main objective of the protest organizer. The Article 23 Concern Group was not the organizer of the 1 July protest, but it endorsed it and its core members took part in it.

50. Margaret $\mathrm{Ng}$ was returned by the Legal Functional Constituency. Audrey Eu, Alan Leong, and Ronny Tong were returned by geographical direct elections. Audrey Eu was an incumbent, while Alan Leung and Ronny Tong ran for the first time.

51. The term was coined by Lau Siu-kai to mean "normative and behavioural tendency of an individual to place his familial interests above the interests of society and of other individuals and groups, and to structure his relationships with other individuals and groups in such a manner that the furtherance of his familial interests is the overriding concern." Lau Siu-kai, Society and Politics in Hong Kong (Hong Kong: The Chinese University Press, 1982), p.72. 
informal groups are an important source of friendship and provide support, emotional and otherwise, to their members. Participation in such groups, aided by close relationship with family members, binds people together.

The results of the survey also show that objective vertical social cohesion is not accompanied by a corresponding level of subjective vertical cohesion. We can again examine Table 9 for plausible explanations. The data there show that the Hong Kong government the chief executive (4.85), his principal officials (4.90), their public policies (4.75) and the style of governance (4.59) - are all felt to damage social cohesion. The link between society and the government appears to be severed. Reasons for this are many and various, but one major issue is the design of the political system. Perhaps first and foremost is the fact that the chief executive and his principal officials are not popularly elected, and they therefore constantly battle with questions of accountability and legitimacy. Present arrangements also permit the possibility of the government pushing policy through the legislature even though the legislature opposes it, making public opinion irrelevant. The power of popularly elected legislators who have the mandate of society is greatly harmed by the obstacles they must overcome in order to move private members bills. Furthermore, the various ways of selecting legislators makes it difficult for them to hold the government in check effectively. ${ }^{52}$

Apart from these structural reasons, our survey shows that the political parties and legislators fail to represent society. The respondents do not trust political parties. They awarded them a score of 4.80, which was very close to that of the chief executive (4.79). Receiving a score of 5.35, the functionally elected legislators failed to reach the midpoint by a small margin, indicating that they, too, were unable to gain the trust of the respondents. Geographical legislators, who have been returned by universal suffrage, did pass the midpoint, receiving a score of 5.66. In theory the political parties and legislators are the main intermediaries entrusted with the job of representing society, yet in Hong Kong they appear to have failed in this. And without this linkage, it is hard for the people to have their voices heeded or their grievances redressed. This situation also makes it more difficult for the government to devise appropriate public policy. The structural arrangements of the political system have greatly compromised the function of political parties to act as links between the government and the people. ${ }^{53}$ Understanding that political parties

52. The structural problem of Hong Kong's political system has been pointed out by a number of scholars. See, for example, Eliza W. Y. Lee, "Governing post-colonial Hong Kong: institutional incongruity, governance crisis, and authoritarianism," Asian Survey, Vol. 39, No. 6 (1999), pp. 640-659; Ian Scott, "The disarticulation of Hong Kong's post-handover political system," China Journal, No. 43 (2000), pp. 29-53.

53. Lau Siu-kai and Kuan Hsin-chi, "Hong Kong's stunted political party system," The China Quarterly, No. 165 (2002), pp. 1010-28. Ian Scott and Joan Y.H. Leung, "Dysfunctional elections and the political system in Hong Kong," Asian Journal of Political Science, Vol. 12, No. 2 (2004), pp. 1-28. 
have only limited power, the people have no confidence in them. Without political parties working as intermediaries, society and the government are, in important ways, decoupled.

Despite poor linkage between society and the government and popular distrust of the government, the respondents were nevertheless concerned about politics, and most of them voted. That society has not been alienated from politics can be attributed to the mass media in general, and phone-in programmes and radio talk shows in particular. Distressed callers can make their case on-air, and by so doing, the officials handling the case are forced to respond publicly. It is widely known that various government departments listen to popular phonein programmes religiously in order to feel the public pulse and to avoid being caught unprepared. Such programmes are very influential in channelling public dissatisfaction and directing public opinion. As shown in Table 8, the survey respondents also regarded them positively, awarding 5.89 to the mass media, and hence seeing them as contributing to social cohesion in Hong Kong. The popularity of these programmes can be further demonstrated by the fact that the host of one phone-in programme won in the 2004 LegCo elections. He secured 25 per cent of all votes in his constituency.

\section{Conclusion}

These findings suggest that Hong Kong presents a mixed picture with regard to social cohesion. While the people of Hong Kong feel quite positive about fellow members of society and usually have a respectable sense of belonging to society, such positive sentiments are to some degree offset by the inertia in social engagement. The opposite seems to be true of vertical cohesion. There, lack of confidence in the government is accompanied by a relatively high degree of conventional political participation. Using the terms of our framework, the people of Hong Kong on the whole scored positively on horizontal/subjective and vertical/objective dimensions, but negatively on the horizontal/objective dimension. On the surface, the vertical/subjective dimension records a positive score too. However, this conclusion has to be qualified, for the score is contaminated by the fact that a lack of trust in the government has been offset by an overwhelming confidence in the institutions of justice.

What holds the society of Hong Kong together is an elusive sense of belonging and identity, and, we postulate, a host of public-serving advocacy groups and perhaps informal groups and personal networks as well. They are facilitated by confidence in the justice maintenance organizations. However cohesive society feels, it is achieved with little institutional mediation and social engagement. Such is the peculiarity

54. Albert Cheng was a host of probably the most popular phone-in programme in Hong Kong until shortly before the LegCo elections. He secured 73,424 votes in Kowloon East, higher than three other incumbents who ran in the same constituency. 
of the state of social cohesion in Hong Kong. It may be true that supporting advocacy groups and joining small groups fit the lifestyle of a modern, computer-connected society, in which social boundaries are characterized as "porousness" and social relationships "loose connections." 55 Nevertheless, whether such forms of association can replace social engagement, which Putman has shown to be positively associated with a more tolerable and equal society, goes beyond this research and requires further investigation. 